\title{
Research into Practice-Promoting Participation, Perseverance and Publications
}

\author{
Thomas F. Döring ${ }^{1,2}$ \\ ${ }^{1}$ Editor-in-Chief of Organic Farming, Librello, Basel, Switzerland \\ ${ }^{2}$ Agroecology and Organic Farming Group, University of Bonn, Bonn, Germany; E-Mail: tdoering@uni-bonn.de \\ Published: 16 May 2018
}

This year, organic farmers, advisors and researchers in the West of Germany celebrate the 25th anniversary of the foundation of an organic research and demonstration network. Established to support and improve organic farming systems, the network is funded by the federal state of North Rhine-Westphalia and is organized around 30 participating pilot farms called Leitbetriebe ('leading farms'), with support from the university of Bonn and the Chamber of Agriculture [1]. For each of the practice-oriented research topics covered in this network, the typical five-year cycle of research involves a first year of experimental exploration and literature studies. The farmers participating in the pilot farm project discuss and select the topics of priority and review the research plans proposed by the scientists. This is followed by three years of systematic replicated field trials on several farms, and a final year of demonstration and evaluation, where the presentation of results is jointly done by farmers and researchers. The topics studied over the last quarter of a century include pre-sprouting of potatoes [2], undersowing [3], fertilization of in oil seed rape [4], species mixtures in pasture systems [5], strategies to reduce nitrogen losses [6], the cut-and-carry system [7], and several more. The participating farms are selected to represent the wide range of environmental conditions within North Rhine Westphalia, where according to the most recent figures nearly 2,000 certified organic farms operated on 78,000 ha of agricultural land [8].

The experience gained over the past 25 years in this organic research and demonstration network confirms and complements the insights obtained in similar operations elsewhere [9]. To be successful, integrative partnerships between research and organic practitioners require perseverance, patience, and reliable funding. In particular, the period of three years that research projects are usually funded for is far too short to establish the trust and mutual understanding necessary for successful implementation of research. Innovations developed in agricultural research just take a long time to be established in practice.

Further, adoption depends on individual advice adapting recommendations for the complexity of individual organic farming systems. In fact, the grassland research within the pilot farm project has highlighted the need to individualize recommendations, partly because of the tremendous effects of interactions between species and genotypes of crops, pasture management and environment. Wider adoption of research also requires a critical mass of farmers acting as innovators, which is more difficult to achieve in the organic sector. Finally, implementation and adoption of research-powered innovations requires continuous dialogue between researchers, advisors and farmers, based on a common language, jointly identified research questions, and active knowledge transfer delivering clear, brief and targeted outputs.

As experience in the pilot farm project has also shown, knowledge transfer in the form of publishing in international peer-reviewed journals is not a necessary requirement for the adoption of research in practice. In fact, international publishing is often not seen as belonging to the culture of participatory research in agriculture. However, it acts as an indispensable tool for quality control within science. It also helps to increase visibility for innovations in organic agriculture on the international stage, thereby generating 
wider feedback. Within a regional farmer-led research network, however, publishing internationally is typically not high on the agenda, despite the great potential to do so, and despite the gains expected from sharing experiences with an international audience. Conversely, practice oriented research is not always appreciated in the academic world.

At its inception, this journal pledged to bridge this gap between practice and research for organic farming [10]. As one of the means to achieve this, the open access publishing model of Organic Farming has so far generated several

\section{References and Notes}

[1] Stumm C, Köpke U. Organic Pilot Farms in North Rhine-Westphalia (Germany). In: Neuhoff D, Halberg N, Alföldi T, Lockeretz W, Thommen A, Rasmussen IA, et al., editors. 16th IFOAM Organic World Congress, Modena. Modena, Italy; 2008. Available from: http://orgprints.org/12594.

[2] Stumm C, Köpke U. Einfluss von Lichtspektrum und Beleuchtungsstärke auf das Keimlängenwachstum und den Ertrag von Kartoffeln. In: Leithold G, Becker K, Brock C, Fischinger S, Spiegel SK A K and, Wilbois KP, et al., editors. 11. Wissenschaftstagung Ökologischer Landbau. Gießen, Germany: Verlag Dr. Köster; 2011. pp. 262-265.

[3] Stumm C, Köpke U. Untersaaten in Kartoffeln zur Reduzierung der Spätverunkrautung. In: Zikeli S, Claupein W, Dabbert S, Kaufmann B, Müller T, Valle Zárate A, editors. 9. Wissenschaftstagung Ökologischer Landbau. Hohenheim, Germany: Universität Hohenheim; 2007. pp. 117-120.

[4] Stumm C, Berg M, Köpke U. Anbau und Düngung von Winterraps (Brassica napus L.) im Ökologischen Landbau, in Werte -Wege-Wirkungen: Biolandbau im Spannungsfeld zwischen Ernährungssicherung, Markt und Klimawandel. In: Mayer J, et al , editor. 10. Wissenschaftstagung Ökologischer Landbau. vol. Band 1: Boden, Pflanzenbau, Agrartechnik, Umwelt- und Naturschutz, Biolandbau international, Wissensmanagement. ETH Zürich. Zürich, Switzerland: Verlag Dr. Köster; 2009. pp. 193-196. thousands of free downloads per issue, thereby promoting the visibility and impact of the published research. Further, this journal will continue to encourage submissions at the interface of organic practice and research, with article formats beyond traditional structures. Finally, an updated and more flexible system is being implemented for publication fees, which includes a post-acceptance fee in addition to the membership model, thereby opening the journal to a wider range of authors.

[5] Leisen E, Vollmer B, Gutberlet K, König ME. Test von KleegrasKräuter-Mischungen in Öko - Milchviehbetrieben. In: Häring AM, Hörning B, Hoffmann-Bahnsen R, Luley H, Luthardt V, Pape J, et al., editors. 13. Wissenschaftstagung Ökologischer Landbau. Eberswalde, Germany; 2015. pp. 419-422.

[6] Berg M, Haas G, Leisen E, Schenke H. Stickstoffmanagement im ökologisch wirtschaftenden Betrieb: Minderung von Stickstoffverlusten: Dokumentation 10 Jahre Leitbetriebe Ökologischer Landbau in Nordrhein-Westfalen. Schriftenreihe des Lehr- und Forschungsschwerpunktes "Umweltverträgliche und Standortgerechte Landwirtschaft". 2003;105:64-75.

[7] Stumm C, Köpke U. Düngung mit Sprossmasse von Futterleguminosen: Lachgasemissionen und Nitratverluste. In: Wolfrum S, Heuwinkel H, Reents HH, editors. 14. Wissenschaftstagung Ökologischer Landbau, Campus Weihenstephan, Freising-Weihenstephan. Freising-Weihenstephan, Germany: Verlag Dr. Köster; 2017. pp. 342-345.

[8] Ökologischer Landbau in Deutschland, Stand: Januar 2018. Bonn, Germany: Bundesministerium für Ernährung und Landwirtschaft; 2018.

[9] Wortmann CS, Christiansen AP, Glewen KL, Hejny TA, Mulliken $\mathrm{J}$, Peterson JM, et al. Farmer research: Conventional experiences and guidelines for alternative agriculture and multi-functional agro-ecosystems. Renewable Agriculture and Food Systems. 2005;20(04):243-251. doi:10.1079/raf2005110.

[10] Döring TF. A Fresh Start for Organic Farming Research. Organic Farming. 2013;1(1). doi:10.12924/of2015.01010001. 